\title{
Local Perception on the Exploitation, the Current State and Taboos Related to Pangolins (Pholidota, Mammalia) by the Communities Living in the Tayna Nature Reserve and Its Surroundings (RNT) North Kivu DRC
}

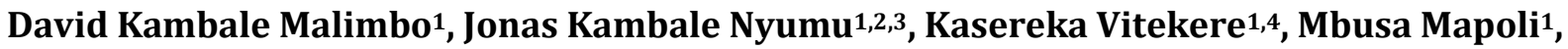 \\ Benzeth Visando ${ }^{1}$, Juakaly Mbumba ${ }^{3}$, Guy Crispin Tungaluna ${ }^{3}$, Francis Tarla ${ }^{2}$, Ngoy Steve ${ }^{1}$ \\ ${ }^{1}$ Department of Ecology and Management of Animal Resources, Kasugho University of Nature Conservation and Development, \\ Goma, DRC \\ ${ }^{2}$ MENTOR-POP (Progress on Pangolin), Zoological Society of London (ZSL-Cameroon), Yaounde, Cameroon \\ ${ }^{3}$ Department of Ecology and Management of Animal Resources, Faculty of Sciences, University of Kisangani, Kisangani, DRC \\ ${ }^{4}$ College of Wildlife and Protected Areas, Northeast Forestry University, Harbin, China \\ Email: louisjuakaly@gmail.com, gembuguycrispin@gmail.com
}

How to cite this paper: Malimbo, D. K., Nyumu, J. K., Vitekere, K., Mapoli, M., Visando, B., Mbumba, J., Tungaluna, G. C., Tarla, F., \& Steve, N. (2020). Local Perception on the Exploitation, the Current State and Taboos Related to Pangolins (Pholidota, Mammalia) by the Communities Living in the Tayna Nature Reserve and Its Surroundings (RNT) North Kivu DRC. Journal of Geoscience and Environment Protection, $8,18-35$.

https://doi.org/10.4236/gep.2020.812002

Received: September 26, 2020

Accepted: December 1, 2020

Published: December 4, 2020

Copyright (๑) 2020 by author(s) and Scientific Research Publishing Inc. This work is licensed under the Creative Commons Attribution International License (CC BY 4.0).

http://creativecommons.org/licenses/by/4.0/

(c) (i) Open Access

\begin{abstract}
Pangolins are currently considered the most endangered mammal species due to their high rank in local and international traffic. This species is protected in DRC and worldwide, unfortunately it is threatened by numerous human actions. The objective of this study is to identify the different reasons for which these animals are exploited, to provide information to determine from the opinions of the respondents the current state of the population from 2015 to today and to identify their hunting techniques by the local populations. We carried out surveys in the households of hunters, farmers and people practicing other professions in 12 villages, located within the RNT and surroundings areas. Two interview techniques were used: the individual interview and the participatory diagnostic technique. 175 people were interviewed individually. Nearly $97 \%$ of our respondents are motivated to consume pangolin as bush meat obtaining by hunting. The main reason for eating pangolin meat is $44 \%$ preference and 33\% habit. The zone does not know the foreign solicitation of the exploitation of pangolins and its derivatives. The opinions of the population regarding the current state of pangolin in the Tayna Nature Reserve indicate that from 2015 to the present day the common pangolin "Manis tricuspis" has been abundant. Hunters use different hunting techniques, dominated by pickup for the Manis tricuspis, digging burrow, fire at the entrance of the burrow for Manis gigantea and the shotgun for the Manis tetradactyla.
\end{abstract}




\section{Keywords}

Local Perception, Exploitation, Current State, Taboos, Pangolins, Communities Tayna Nature Reserve, North Kivu/DRC

\section{Introduction}

Surveys of local ecological knowledge, ethnobotany, ethnozoology and local perception can be considered as an important complementary method for obtaining useful conservation data, particularly for large vertebrates and small to medium-sized species of mammals such as occurrence data and information on local use and conservation perspectives (Turvey et al., 2015; Nash et al. 2016). Protected Areas and forest massifs constitute remarkable habitats for wildlife (Mbete, 2012). In forest areas where it is the main source of animal protein, there are few livestock alternatives for the supply of animal protein. To this end, bushmeat is an important source of protein in the diet of the people of the Congo Basin (Willcox \& Nambu, 2007). The people of the Congo Basin have always practised customary self-subsistence hunting. This has an important place in the economic and cultural organisation of logging companies (Wright \& Priston, 2010). Currently, it has become an activity generating incomes in both rural and urban areas. Moreover, the profit from hunting of wildlife has increased rapidly in recent years as it started to be a crime of capital importance. Due to it, the commercial wildlife hunting has grown exponentially (Abernethy et al., 2013) and is considered to be the principal reason of the bushmeat demand in Central Africa (Nasi et al., 2011; Van Vliet et al., 2012).

Pangolins (Pholidota: Manidae) are symptomatic of this trend, having historically been exploited throughout their range in Africa and Asia and are currently threatened by international traffic and local use (Waterman et al., 2014). They are also used in rituals, art, and magic between communities across Africa (Soewu \& Sodeinde, 2015) and Asia (Mahmood et al., 2012). The scales covering the dorsum, flanks, tail and which make them appear like a reptile are one of the principal reasons for their high exploitation (Malimbo et al., 2020). This has led to a population decline in Asia (Wu et al., 2004), an increasing risk of extinction in Africa and Asia (Waterman et al., 2014), and pangolins being considered a group of trafficked wild mammals. Although demand for pangolin products in Asia has traditionally been met by local supply or by regional range states, an apparent increase in seizures of African pangolin derivatives (almost exclusively in scales) in Asia, Europe travelling to Asia; and Africa for Asian markets over the last decade suggests that Asian demand is now partly met by African pangolins (Challender \& Waterman, 2017). Their ecological traits and behaviors, such as poor eyesight and their mechanism of defense, make them highly susceptible to overexploitation (Sodeinde \& Adedipe, 1994). All eight species of pangolin are globally threatened due to both local demands in pangolin range states and increasing 
international demands for pangolin scales in parts of Asia (IUCN, 2019). Judging by the current evidence, pangolin populations occurring in China seem to be commercially extinct and the local demand increasingly seeks pangolins in other parts of Asia or in Africa (Pantel \& Anak, 2010; Challender \& Hywood, 2012; Gomez \& Leupen, 2016; Challender \& Waterman, 2017; Mambeya et al., 2018).

Ingram et al. (2018) suggest that between 0.42 and 2.71 million pangolins were killed annually in West and Central Africa in the sampled period 1975-2014 leading to the increase of hunted pangolins over time in markets. There are few population estimates for the four African species (black-bellied pangolin M. tetradactyla, white-bellied pangolin, $M$. tricuspis, giant pangolin $M$. gigantea or Temminck's ground pangolin, M. temminckii Pietersen et al. (2014). However, there is evidence that they are consumed as wild meat and their body parts are used in a wide range of ethnopharmacological applications (Boakye et al., 2015). Three pangolin species occur in the Democratic Republic of Congo, namely the white-bellied pangolin (Phataginus tricuspis), black-bellied pangolin (Phataginus tetradactyla) and the giant ground pangolin (Smutsia gigantea) (Kingdon \& Hoffmann, 2013). However, there is a shortage of official data about pangolins in the D.R Congo and the only existing information sources refer to bushmeat markets or pangolin seizures.

In the review of hunted pangolins in sub-Saharan Africa done by Ingram et al. (2016), it was summarized that the median percentage of the total number of individual hunted pangolins was 0.18 based on the studies between 1972 and 2014 and 0.28 for pangolins offered at local markets by virtue of the studies conducted between 1970 and 2013, involving all species of pangolin. Based on the results of a study of the bushmeat market in DR Congo, Colyn et al. (1987) report that pangolins are among the groups of animals captured and less sold on the market. They attribute this to the fact that consumption of pangolins is considered as a taboo in certain regions of the country, particularly in the East. Today, bushmeat researchers are concerned about the amount of bushmeat sold in the region's markets, particularly pangolin meat (Van Vliet et al., 2014). Recently, Ingram et al. (2018) estimated that between 0.4 and 2.7 million pangolins are harvested annually for game meat in Central Africa, and that the proportion of pangolins among all captured animals has increased over time.

In addition, there is limited quantitative information available on levels of human use, making it difficult to assess the conservation status of the pangolin. There is a lack of knowledge about the fate of the "pangolins" in the Democratic Republic of Congo, millions of which are exploited every year. In the RNT, pangolins are exploited and hunted for their meat and scales without regard to their conservation status, which negatively influences their current population state (Malimbo et al., 2020). It is in this context of unsustainable exploitation of wildlife resources in general and those protected in this case the pangolins that we conduct a local perception on the exploitation, current state and taboos related to pangolins by the inhabitants of the RNT and its surroundings. Within the community survey, the research aims to answer the following key question: What motivating the local community to exploit the pangolins in our study 
area? What is the recent pangolin status from 2015 to 2020 according to the opinions of local community? At the socio-cultural level, what are the beliefs, habits and customs pertaining to the pangolin within the RNT and its surroundings? What are the pangolins hunting techniques used by the inhabitants of the Tayna Nature Reserve and its surroundings?

In this study, we want to document the reasons for pangolin exploitation, the opinions of the local population on the current state of pangolin populations in the RNT and its surroundings and taboos related to pangolins. More specifically, we want to determine 1) the motivations for the exploitation of the pangolins by the population of Tayna and those living in vicinity to the reserve, 2) identify the current state of the pangolins based on the opinions of this population, 3) identify the beliefs, habits and customs of the inhabitants of the RNT with respect to the Pangolins and 4) Identify the hunting techniques used for the capture of pangolins. To achieve these objectives, we conducted a survey in the villages of the RNT and its surroundings, one of the areas of the pangolin range in Central Africa.

\section{Methods}

\subsection{Study Area}

This study was conducted in and around the Tayna Nature Reserve (Figure 1), in the East part of the Democratic Republic of Congo (DRC) and covers more or less $900 \mathrm{~km}^{2}$. Tayna Nature Reserve was established in 1998, approved and launched by the administration of North-Kivu Province in 1999. This Protected Area is located at $350 \mathrm{~km}$ northwest of Goma, the capital city of the province of North-Kivu. It remains an integral part of the "Maiko-Tayna-Kahuzi Biéga Landscape", a hotspot of a worldwide renown due to its importance of fauna and

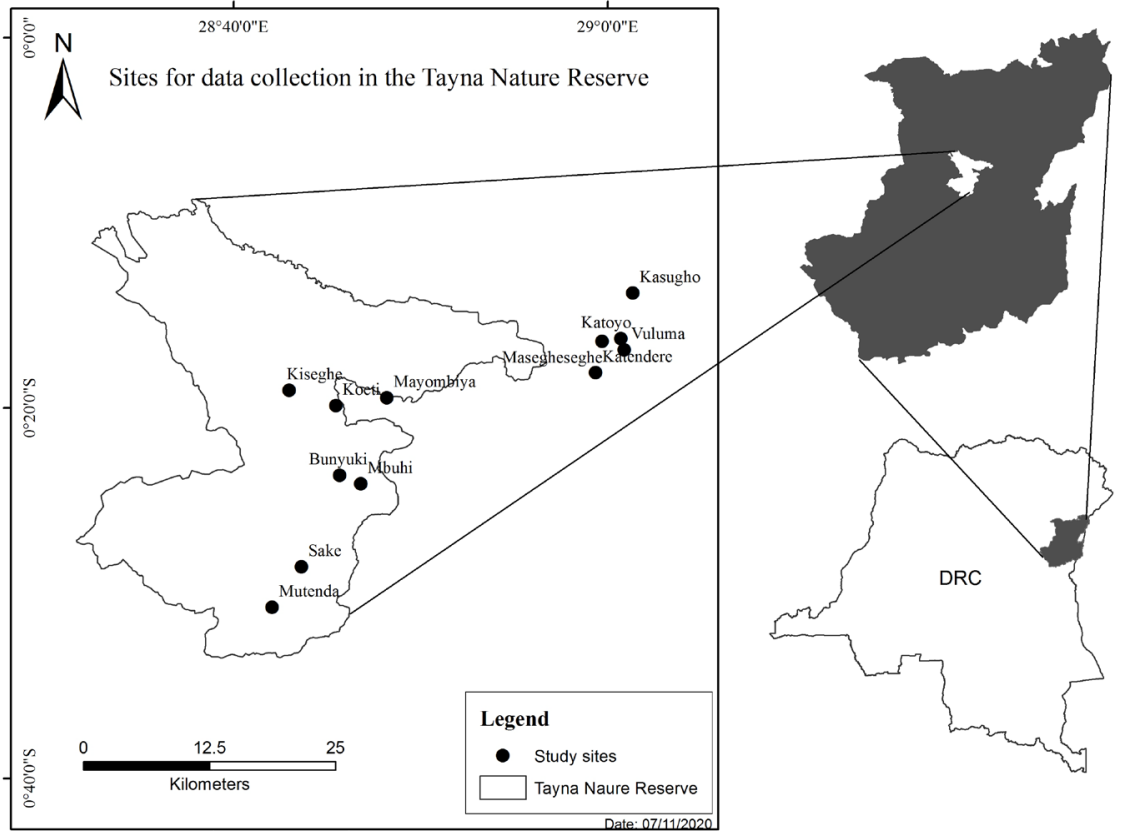

Figure 1. Study area and the location of sampling sites (villages) within the RNT. 
flora. This landscape shelters a rich mammalian fauna of Elephants (Loxodonta africana cyclotis), Okapi (Okapia johnstoni), Buffaloe (Syncerus cafer nanus), many species of primates the Eastern lowland gorilla (Gorilla beringei grauweri), chimpanzee (Pan troglodytes), the eastern black-and-white (Colobus guereza) the Hamlyn's monkey (Cercopithecus hamlyni), the red-tailed monkey (Cercopithecus ascanius), three species of pangolins: the giant pangolin (Manis gigantea), the white bellied pangolin (M. tricuspis) and the long-tailed pangolin ( $M$. tetradactyla), and a high diversified avifauna. The vegetation is the equatorial forest since the reserve is located in the Congo basin forest bloc, where it rains the whole year. The area is constituted by a monotone human population as only three tribes are represented. These tribes remain the autochthones population of this area.

\subsection{Sampling Methods}

The traditional leaders of the study area were contacted at the beginning of the surveys for their support and collaboration. Community based surveys (individual interview and focus groups surveys) were conducted in the villages located inside and outside the RNT. A full list of villages was obtained from the Reserve administration authority, and we randomly selected 12 villages to conduct our investigations. After determining the number of households to be surveyed in each village or stratum with the help of local chiefs, the choice of households to survey was made randomly. The villagers' houses being arranged in a linear fashion on either side of the road, the households to survey were chosen at the interval of 3 (sampling fraction), thus we were investigating each time the third household from the first chosen. Men, women and different socio-professional categories had the same chance of being interviewed (equiprobability sample). Children and teenagers below 18 years were not interviewed. To ensure independence of responses one respondent only was interviewed per household, and respondents of both genders exerting any kind of occupation were interviewed.

\subsection{Data Collection and Technique}

We used two techniques: 1) the interview survey with a survey questionnaire and 2) a documentary technique used by a literature review to understand and define the theoretical framework of our study. The survey questionnaire was completed during the meeting by discussions with the targeted population. We used individual interviews and the participatory diagnostic technique which was carried out in the focus groups (Figure 2). The Focus-Group allowed gathering the opinions of people in small groups (e.g. Bahige, 2009) about pangolins exploitation. After developing the survey questionnaire, we translated in local language (Swahili). The survey form was administered in the villages, Monday to Saturday from 4:00 p.m. to 6:00 p.m. and Sunday from 8:00 a.m. to 5:00 p.m. We chose these hours because most farmers and hunters had already returned from the fields and were resting at home. In addition, standardized, structured, and semi-structured questionnaires were administered to 175 local people from 12 


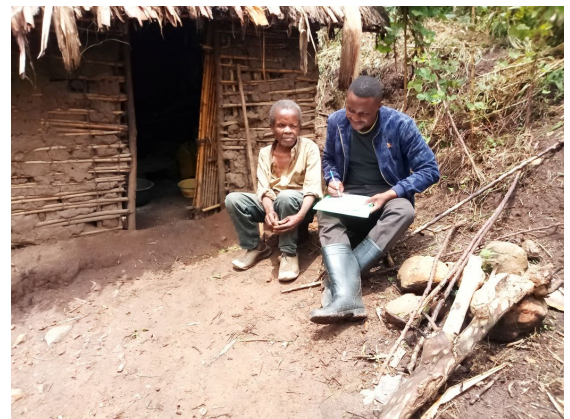

(a)

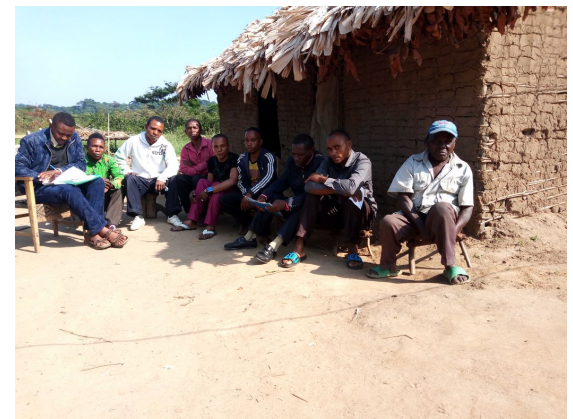

(b)

Figure 2. (a) Individual interview; (b) Focus group during the data collection within the RNT.

villages from the study areas. Completion of the questionnaires was done "face-to-face" with the respondents, who were randomly selected. To reduce bias, we followed a structured questionnaire, while standardized questionnaires were used to ensure the reliability, generalizability, and validity of the responses. In order to collect as much information as necessary, opened questions (about the species' specific characteristics allow respondents to discuss their personal beliefs, attitudes and opinions towards the pangolin) were asked at the end of the structured portion. The households' chiefs who were mainly men, were interviewed. However, in their absence, housewives who were willing to participate were interviewed.

\subsection{Respondents' Profiles}

We chose to survey 175 people from three ethnic groups: Nande, Piri and Nyanga. Almost all respondents were men and few were women in all villages surveyed. Most of our respondents were in the 20 - 30 age group (30.1\%) while $18.5 \%$ were in the 40 - 50 age group and only $6.9 \%$ were in the over-60 age group. Most of our respondents had not studied and those with some primary education. The main occupations of the respondents were farmers followed successively by hunters and government officials.

\subsection{Data Analysis}

To document the categories of people related to the reasons and methods of acquiring pangolin products, the population's opinion on the current state of pangolins and the taboos related to pangolins, we calculated the frequency using the equation:

$$
\%=n / N \times 100
$$

Equation (1) is the frequency formula which \% is percentage or frequency, $n$ : represents the category of the sample and $N$ : is the total number of the whole gathered sample. To bring out differences in respondents' responses such as testing if the exploitation reasons of pangolin meat are fairly distributed; to test the efficiency of methods used for gathering pangolin and their products; to test 
if living in a specific village and belonging to a specified tribe could influence the taboos related to the pangolin, we used Chi-square tests with the R software.

\section{Results}

\subsection{Reasons of Pangolin Exploitation and the Methods in Gathering Pangolins}

Overall, $97 \%$ of our respondents eat pangolin as bushmeat and only $3 \%$ confirm that they do not eat it for various reasons such as repulsive animal, with a strange smell and resemblance with Reptiles each represented by $1 \%$. The preference of pangolin meat is the main reason for eating pangolin meat (44\%), successively followed by habit (33\%) and health care (19.3\%) according to our surveys (Figure 3 ). The amulet as another reason to eat pangolin meat is hardly represented by $2.8 \%$. The chi-square test of adequacy indicates that the frequencies of responses on the reason for the exploitation of pangolin meat are not fairly distributed ( $p$-value $<0.01$ ), thus the surveyed population mainly consumes pangolin meat by preference and habit.

Among the whole sample, $47 \%$ recognized hunting as the method of obtaining pangolin meat followed by the collection by chance in the forest at $33.1 \%$ and purchasing at $19.9 \%$ (Figure 4 ). The adequacy test with the distribution of staff ( $p$-value $<0.01$ ) shows that hunting is the most widely used method to acquire the pangolin.

\subsection{Information on the Trade of the Pangolin or Its Scales by People from Other Backgrounds}

Referring to the trade of pangolin in the RNT, $96 \%$ of respondents do not recognize the solicitation of people from other places to request pangolin while $4 \%$ of

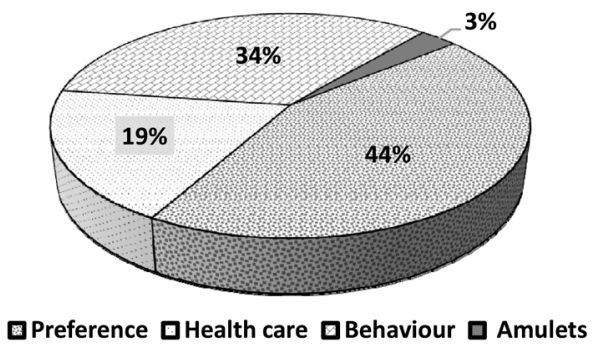

Figure 3. Reasons for pangolin consumption by local people of the RNT.

Chi-square $=32.439, \mathrm{ddl}=2 ; \mathrm{p}$-value $=9.035 \mathrm{e}-08$

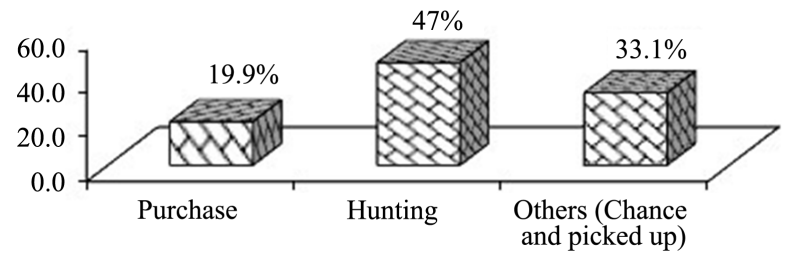

Figure 4. Methods for gathering pangolins and its derivatives products within the RNT. 
respondents confirmed that people from elsewhere come to request pangolin or its scales. These people come from the Tshopo province.

\subsection{Information on the Sale of Pangolin: By Resort and by Villages}

In the Kabwekandongwe station, information on the sale of pangolin and its scales was only superficially known (Figure 5), whereas in the Bunyuki station, information on the sale of pangolins and its scales was accidentally quoted.

\subsection{Local Opinion about Current State of the Pangolins in the Tayna Nature Reserve and Its Surroundings from 2015 to 2020}

In order to highlight the trend in the current status of pangolins in the area since 2015, three species were reported to occur in the RNT and its surroundings. This study revealed that pangolins are present in the Tayna Nature Reserve and its surroundings (Figure 6). Respondents had mixed perceptions on the status of three pangolins species in and around the RNT. Here we note that Manis gigantea is recognized as rare, Manis tricuspis abundant followed by Manis tetradactyla.

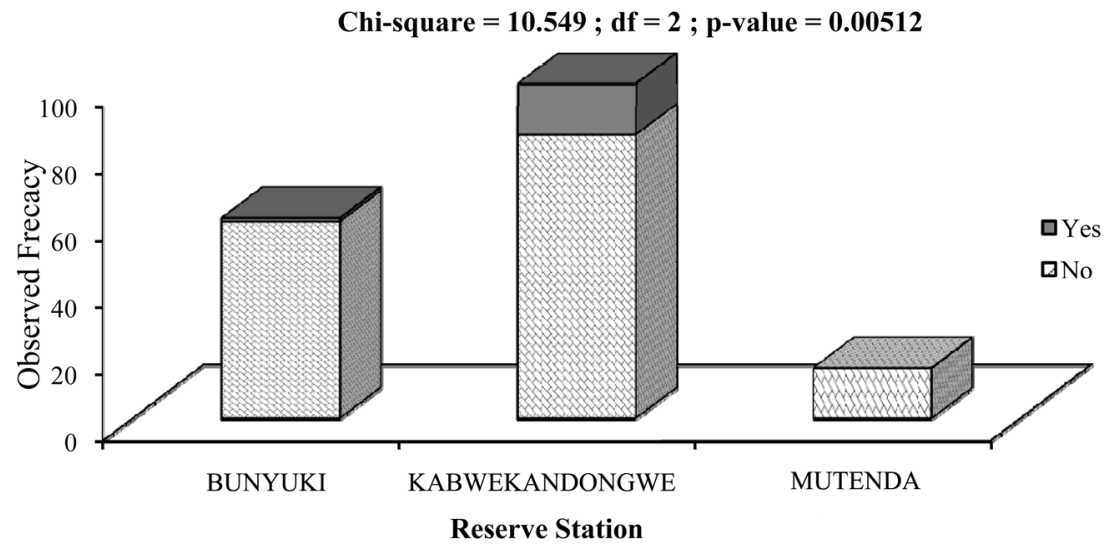

Figure 5. Sale of pangolin in RNT stations.

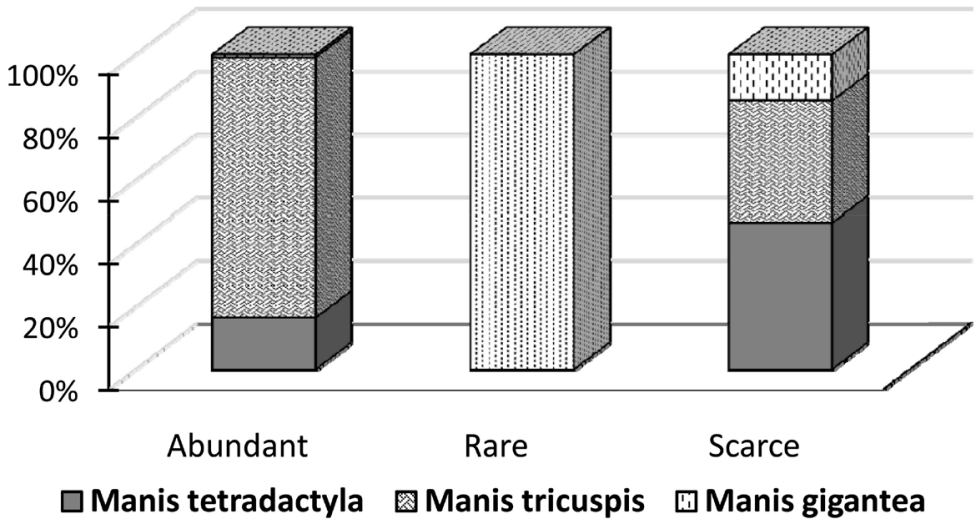

Figure 6. Population status of pangolins in the RNT and its surroundings from 2015 to date. 


\subsection{Different Taboos Related to Pangolins}

Several taboos are recognized by the inhabitants of the Tayna Nature Reserve and its surroundings according to tribes and villages as shown in Table 1.

This table indicates that $65 \%$ of the Nande do not recognize any taboo related to pangolin while $29.03 \%$ of the Piri recognize the taboo related to this animal followed by the Nyanga at $5.38 \%$. It has also been found that only men consume its meat in the Verandah at the level of $45 \%$ among the Piri, followed by $35 \%$ among the Nande and finally $20 \%$ among the Nyanga. This meat is banned among Nande women at $67,35 \%, 30,61 \%$ among the Piri and $2.04 \%$ among the Nyanga. It is also outlawed in epileptics $(66,67 \%)$ in the Nande, $33,33 \%$ in the Piri and nothing to report in the Nyanga. Only the meat of the giant pangolin before it is eaten must first be given to the customary chiefs $100 \%$ in the Nande and it is used during the enthronement of the customary chiefs always in the Nande. Also, Pangolin meat was consumed in initiation ceremonies for young men only among the $100 \%$ Nande.

\subsection{Pangolin Hunting Techniques}

In general, the hunting techniques for pangolins vary from one species to another and for some, a synergy can be reported (Figure 7). For Manis gigantea, two hunting techniques are used: Digging burrow and Fire at the entrance of digging. While Pickup remains the only method used for Manis tricuspis and Manis tetradactyla, it is mainly the Shotgun (Fusil) and the hunting dog.

Table 1. Taboos related to the Pangolins according to the tribe and villages of the respondents.

\begin{tabular}{|c|c|c|c|c|c|c|c|}
\hline & $\begin{array}{l}\text { No } \\
\text { taboos }\end{array}$ & $\begin{array}{l}\text { Only men } \\
\text { consume it } \\
\text { on the veranda }\end{array}$ & $\begin{array}{l}\text { Prohibited } \\
\text { to pregnant } \\
\text { women }\end{array}$ & $\begin{array}{l}\text { PG meat eaten after } \\
\text { giving a thigh to the } \\
\text { customary chief }\end{array}$ & $\begin{array}{l}\text { Prohibited to } \\
\text { epileptics }\end{array}$ & $\begin{array}{l}\text { Meat eaten in } \\
\text { initiation ceremonies } \\
\text { for young men }\end{array}$ & $\begin{array}{l}\text { PG meat used at the } \\
\text { enthronement of the } \\
\text { customary chief }\end{array}$ \\
\hline Nande & 65.59 & 35.00 & 67.35 & 100.00 & 66.67 & 100.00 & 100.00 \\
\hline Nyanga & 5.38 & 45.00 & 2.04 & 0.00 & 0.00 & 0.00 & 0.00 \\
\hline Piri & 29.03 & 20.00 & 30.61 & 0.00 & 33.33 & 0.00 & 0.00 \\
\hline Test result & \multicolumn{7}{|c|}{$\begin{array}{c}\mathrm{X} \text {-squared }=54.183, \mathrm{df}=12, p \text {-value }=2.534 \mathrm{e}-07 \\
\text { Fisher's test: } p \text {-value }=0.0004998\end{array}$} \\
\hline BUNYUKI & 7.53 & 5.00 & 4.08 & 41.67 & 0.00 & 0.00 & 71.43 \\
\hline KASUGHO & 12.90 & 0.00 & 6.12 & 0.00 & 0.00 & 0.00 & 0.00 \\
\hline KATENDERE & 5.38 & 0.00 & 20.41 & 0.00 & 33.33 & 0.00 & 0.00 \\
\hline KOTOYO & 8.60 & 15.00 & 8.16 & 8.33 & 0.00 & 0.00 & 0.00 \\
\hline KISEGHE & 9.68 & 0.00 & 2.04 & 0.00 & 0.00 & 0.00 & 0.00 \\
\hline BIAKILI & 5.38 & 0.00 & 20.41 & 0.00 & 0.00 & 0.00 & 0.00 \\
\hline MASEGHESEGHE & 8.60 & 0.00 & 10.20 & 0.00 & 0.00 & 100.00 & 0.00 \\
\hline MAYOMBIYA & 10.75 & 5.00 & 8.16 & 0.00 & 0.00 & 0.00 & 0.00 \\
\hline MBUHI & 6.45 & 0.00 & 6.12 & 41.67 & 33.33 & 0.00 & 28.57 \\
\hline MUTENDA & 3.23 & 45.00 & 6.12 & 0.00 & 0.00 & 0.00 & 0.00 \\
\hline SAKE & 7.53 & 30.00 & 4.08 & 8.33 & 33.33 & 0.00 & 0.00 \\
\hline VULUMA & 13.98 & 0.00 & 4.08 & 0.00 & 0.00 & 0.00 & 0.00 \\
\hline Test result & \multicolumn{7}{|c|}{$\begin{array}{c}\mathrm{X} \text {-squared }=220.78, \mathrm{df}=66, p \text {-value }=2.2 \mathrm{e}-16 \\
\text { Fisher's test: } p \text {-value }=0.0004998\end{array}$} \\
\hline
\end{tabular}




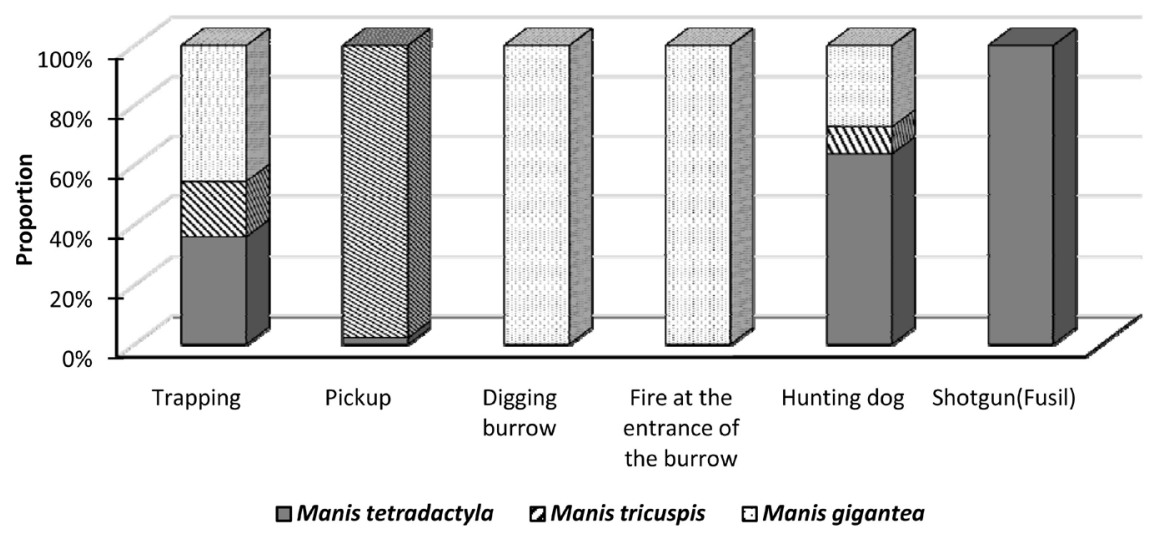

Figure 7. Hunting technique Pangolin.

\section{Discussion}

\subsection{Reasons of Pangolins Exploitation and Gathering Methods within the RNT}

1) The great majority exploits the pangolins for consumption purposes (97\%) when the remaining minority denied eating pangolin meat for various reasons (repulsive animal, its strange smell and resemblance to Reptiles). The consumption of pangolin meat is spread in this species' distribution areas, despite the protection measures implemented in most of these countries, as found also in Ghana (Boakye et al., 2015). Colyn et al. (1987) were the first to highlight the qualitative importance of the consumption of small and medium sized mammalian game in the forest region of DRC. They also stressed that not all taxa are exported to urban markets. Our findings support their opinion that the Pholidota particularly the pangolin and other small or medium size species of game (Carnivores, Hyracoids, Macroselides, Rodents, Squamates and Tubilidae) are mainly consumed in rural areas. Nonetheless, in other parts of Africa (Zimbabwe), findings demonstrate that pangolins have been harvested or hunted not only for bushmeat but for cultural purposes including traditional medicine (Shepherd et al., 2017; Soewu \& Sodeinde, 2015). The consumption of pangolin bushmeat is an integral part of the preferences and eating habits of the inhabitants of the RNT and its surroundings, and it has been revealed that local people use pangolin derivatives for medicinal and spiritual intents (protection or talisman).

2) The assessment indicated that all reasons (preferences, habits, health issues and talisman purposes) are proportionally revealed, yet with preferences and habits mostly cited. This consumption represents an important source of proteins for households as bushmeat is the main protein sources for African forest people (Van Vliet \& Mbazza, 2011; Challender \& MacMillan, 2014) and contributes to the populations' therapy for various diseases.

3) However, bushmeat is also consumed in great cities (Van Vliet et al., 2014) as a luxury meat. There is a real attachment of the forest populations of the Congo basin to their traditional diet; they are therefore in a state of dependence 
on a nurturing environment which also constitutes their capital (Willcox \& Nambu, 2007). In the whole Africa and abroad, pangolin meat was once considered as an additional source of protein. Recently, it is now considered as a delicious dish consumed by the wealthy people in China and Vietnam which pangolin meat was available in the high luxury restaurants, and was the most expensive meat, with $89 \%$ of consumers (Vallianos \& Challender, 2016). Another study depicting similar findings carried out in Nigeria (Soewu \& Adekanola, 2011), revealed the high market value attributed to this species' derivatives was regularly found.

4) The methods to acquire pangolin meat and its derivatives depend on their availability. In the RNT, the half of actors confessed that hunting is the most used for acquiring these products, as hunting is a common activity in forest people of the Congo basin (Caspary, 1999). On the other hand, Soewu and Ayodele (2009) brought out that the principal way to acquire pangolin products in Nigeria was hunting and pangolin individuals can be purchasing from hunters or consumers undertake their own hunting activities. Since pangolin is a slow species for walking, it can be sometimes found by chance in the forest and this method covered only (17\%) in our study when for Soewu and Ayodele (2009) it represented $10 \%$. Nevertheless, in both cases, the same method is well represented, and it stressed that species habits or physical aspect would also represent a source of threats.

\subsection{Information on the Demands of the Pangolin or Its Scales by People from Other Backgrounds}

In Tayna, pangolins were collected from the wild for bushmeat and cultural purposes, including traditional medicine (Malimbo et al., 2020). For the commercial exploitation of pangolin and its derivatives in our study area by people from elsewhere, that the population of Tayna and its surroundings are less familiar with the outside world. Only $4 \%$ of our respondents confirmed that people from elsewhere come to request pangolin in the Tayna Nature Reserve. It is only in the village of "Masegheseghe" out of the twelve respondents that this information was much mentioned. They specify that those people come from Kisangani or the Province of Tshopo in general. This is consistent with the information provided by Congolese Institute for the Conservation of Nature (ICCN)/Province of Tshopo and its partners who report more than 2.5 tons of scales seized in 2017, by these field agents, where the cargo originated from the Kisangani-Buta road (Bas-Uéle Province), probably in the forests surrounding the Tshopo province (ICCN/DRC/PN/Tshuapa Lomami-Lualaba-Comm person,). To this is added the seizure of $73 \mathrm{~kg}$ of M.gigantea scales intercepted by guards in Garamba National Park (Northeastern DRC) in collaboration with the non-governmental conservation organization, African Parks (African Parks, 2017). We believe that, as Tayna is landlocked and once insecure, it can slow down the external solicitation of pangolin products. With regard to the village of Masegheseghe, which has experienced this solicitation, we suppose that as it is 
located in the development zone of the RNT and gives access to the core area of the reserve is the cause of non solicitation of pangolins and its scales. However, we also found that as we progressed through the integral conservation area, this information was no longer mentioned by the inhabitants of the RNT.

\subsection{Current State of the Pangolins in the Tayna Nature Reserve and Its Surroundings}

Although there is almost no information on the biology, ecology and population status of pangolins in Africa, the species is known to be in serious decline throughout its collective range. Several studies carried out on pangolins from Africa and Asia indicate a continuous decrease in the size and number of pangolins captured in the forest and an increasing difficulty in encountering the animal. Sodeinde and Adedipe (1994) used an extinction sensitivity rating to predict the long term fate of pangolins if exploitation continues unabated. The extinction risk index for pangolin species was estimated to be 0.68 . This reinforces the observation that today pangolin populations are reportedly severely depleted in parts of their range, which is attributed to hunting for local use and international trade.

In addition, the majority of communities involved in the exploitation of endangered species are often unaware of the conservation status of a given species and the legal consequences of their actions. Vitekere (2015) argues that until these communities better understand these legal implications and why they are imposed, they will be less enthusiastic about changing their attitudes and actions. Our results obtained (Figure 6), according to the opinions of our respondents, show that the three species of pangolin are known to be present in the RNT and the current state of the pangolin population has confirmed the presence of three species of pangolin evaluated as follows, the common pangolin is abundant, the long-tailed pangolin is scarce and finally the giant is rare.

Soewu \& Sodeinde (2015) argue that ignorance of the conservation status of local wildlife and the laws governing its use, lack of conservation education in formal curricula at most levels of the education system, and lack of enforcement of existing laws and regulations are aggravating factors in wildlife exploitation. This generic study on the exploitation of pangolins in the RNT and its surroundings also collected a wealth of data on the species, threats, uses of pangolin and its derivatives, and local beliefs about pangolins, all of which are essential for effective conservation management of the species.

Prior to our survey, international and regional concerns had been expressed that, compared to Asian pangolins, less is known about African species: common pangolin (Manis tricuspis), long-tailed pangolin (Manis tetradactyla), giant pangolin (Manis gigantea), and Temminck's pangolin (Manis temminckii), and no recent baseline data on the regional status of the pangolin was available to critically assess this possibility. They are currently classified as "Vulnerable" by IUCN (Pietersen et al., 2014). Challender \& MacMillan (2014) note that African pangolin populations are declining due to habitat degradation and loss, hunting, 
and increasing demand from international markets (Challender \& Hywood, 2012).

However, little is known about the population size, reproductive potential, and trade of the African pangolin. Fa and Peres (2001), estimating 420,000 pangolins hunted annually per zone, corresponds to a previous estimate of 400,000 M. tricuspis and 100,000 Manis gigantea per year in Central Africa, although based on fewer studies and excluding Manis tetradactyla. The above observation is consistent with the observation reported by the population of Tayna and its surroundings in our study that the common pangolin Manis tricuspis is known to be abundant, the Manis tetradactyla scarce and Manis gigantea rare.

The population status of giant and long-tailed pangolins have been concomitantly estimated to be rare and scarce in the RNT population and its surroundings, which is similar to what has been reported by (Kingdon \& Hoffman, 2013; Ichu et al., 2017). While common pangolins are the most commonly captured (Ingram et al., 2018). In addition, common pangolins are thought to occur at higher densities than other pangolin species (Willcox et al., 2019) and its semi-arboreal lifestyle likely increases the rate at which these pangolins are encountered.

\subsection{Different Taboos Related to Pangolins}

Overall, pangolin species are, in some communities in the DRC, indistinctly (small and large pangolins) protected by their customs. Indeed, pangolin species are subject to cultural bans, particularly among the "Lele" and "Lega" tribe of the DRC. Moreover, among the "Lele", all species are indiscriminately protected; the animal occupies the center of ritual life as a "spirit" animal par excellence, because it transcends all categories by its constitution: body and tail are similar to that of a fish (covered with scales), it walks on all fours, it climbs trees; it is a "mediator" between men and spirits' Heusch et al., 1993. Our study indicated that the population of the Tayna Nature Reserve and its surroundings is heterogeneous, characterized by a great diversity of ethnic groups with a wide variety of customs and taboos to pangolin. The three ethnic groups mentioned the following pangolin related taboos: only men consume its meat in the Verandah. This meat is banned for Nande, Piri and Nyanga women. It is also outlawed to the epileptics in the Nande, the Piri whereas nothing is mentioned on this subject in the Nyanga. The reason given for this belief is that the pangolin rolls upon itself in case of danger, if the epileptic ate this meat, as soon as he falls into syncope, he would roll up like the pangolin and would not have any contraction movements. Only among the Nande, before consuming the meat of the giant pangolin, whoever catches it must first pay a leg to the customary chefs. Moreover, the giant pangolin was used during the enthronement of customary chiefs but also its meat was consumed during the initiation ceremonies of young men. This is consistent with Heusch et al. (1993), who stated that among the "Lega", or giant pangolin, is a matter for the customary chiefs or "Bami" and their con- 
secration rituals. Only the "Bami" who is the Chief of high rank or the person designated by one of them, is authorized to touch it in case a lifeless "Ikhaga" is found in the wild. Anyone who contravenes these cultural prohibitions is severely punished, at the cost of life or family members. For them, the great pangolin in the eyes of the "Lega" is considered a cultural hero who inspired men the art of building houses by the fact that the superimposition of "scales" on the body of the pangolin evokes the leaf tiles whose "Lega" cover the roofs of the huts.

\subsection{Hunting Technique}

Challender (2011) in these studies on Asian pangolins demonstrates that this is the effect of the persistent legal and illegal hunting of Asian pangolins for illegal international trade, largely to meet Chinese demand for meat and scales used in traditional medicine. Hunting technique also influences the type of exploitation and the number of animals caught (Nasi et al., 2011). The exploitation of pangolins within RNT and its environs indicates that pangolin hunting techniques vary from one species to another and from one village to another. For the Manis gigantea, for example, dipping burrow and fire at the entrance of burrow proved to be the technique most used in its capture in 12 villages, while for the Manis tricuspis, pickup was the technique most used in overall villages. The Manis tetradactyla as for him, to hunt him several methods are put in synergy: shotgun (fusil), hunting dog and are widely used in all villages. This observation on pangolin hunting techniques in different villages in our study area further confirms, although partially, our fourth hypothesis, which concerns the technique of pangolin hunting, which would be trapping, collecting and digging burrows.

Boakye et al., 2016 recognize that species such as pangolins, which have low reproductive rates, are at greater risk of extinction because they are less resilient and able to recover from increased mortality under human hunting pressure. Nevertheless, knowledge of hunting techniques is of biological value. It makes it possible to bring an appreciation of the whole of the hunting activity in an environment. Trapping is the most common method of trapping nowadays, without neglecting the hunting dog and the locally made twelve-gauge shotgun. For the sustainability of this activity, the question of selection persists.

\section{Conclusion}

This local perception based approach allowed us to collect baseline data on pangolin exploitation in the RNT and to gain the trends insight in the current population status of three pangolin species (M. tricuspis, M. tetradactyla and M. gigantea) from 2015 to 2019 in the region as perceived by the local community. It also helped to understand the different taboos that the local community in the RNT accords to pangolins and identified the different techniques used to hunt pangolins.

We clearly show that the strong motivations often associated with the hunting 
of pangolins encourage hunters to go deeper into the natural habitat of this animal. The reasons why our respondents exploit pangolins are diverse, ranging from the reason for the exploitation of this animal in their meals as bush meat and the use of its products in traditional medicine. The common pangolin $(M$. tricuspis) is known by the Tayna population and its surroundings to be abundant, the long-tailed pangolin ( $M$. tetradactyla) to be scarce, and the giant pangolin (M. gigantea) to be rare. In addition, we clearly show that the trade of pangolin and its derivatives is not well known in the area. Only the Kabwekandongwe station out of the three surveyed made a slight mention of this solicitation.

Regarding taboos related to pangolin, three ethnic groups living in and around the RNT mentioned the following taboos related to pangolin: only men from these three tribes consume the pangolin meat on the verandah. This meat is forbidden to women in all three tribes. It is also forbidden to epileptics among the Nande and Piri. While nothing has been reported among the Nyanga on this subject. Exceptions have been revealed among the Nande, before consuming the meat of the giant pangolin, whoever catches it must first pay a leg to the customary chefs. In addition, pangolin was used during the enthronement of customary chiefs but also its meat was consumed during the initiation ceremonies of young men. The population of Tayna and its surroundings uses several techniques to hunt pangolins depending on the species, ranging from traditional traps to locally made 12 gauge rifles. The most popular are pickup for the Manis tricuspis, digging burrow, fire at the entrance of the burrow for Manis gigantea and the shotgun for the Manis tetrada.

Our results are striking for the development of conservation management policy for this group of endangered mammals in DRC, in particular, the reasons for its exploitation, the sale of pangolins in the area, the opinions of the local population on the current state of the pangolin and their hunting techniques should be considered. In addition, these results will serve as a wake-up call for RNT managers and the political and administrative authorities of the DRC on the measures to be taken to avoid serious problems of over-exploitation of this mammal, which is supposedly protected by the country's laws. Therefore, we recommend conducting long-term studies of this character and to also establish novel monitoring techniques of pangolins in the wild.

\section{Acknowledgements}

We are grateful to the Chairman of the RNT Board of Directors and the RNT Terrier Chiefs for agreeing to have the local population participate in this study. We also acknowledge the contributions of US FISH for their technical and financial support for this research.

\section{Conflicts of Interest}

The authors declare no conflicts of interest regarding the publication of this paper. 


\section{References}

Abernethy, K. A., Coad, L., Taylor, G., Lee, M. E., \& Maisels, F. (2013). Extent and Ecological Consequences of Hunting in Central African Rainforests in the Twenty-First Century. Philosophical Transactions of the Royal Society B: Biological Sciences, 368, Article ID: 20120303. https://doi.org/10.1098/rstb.2012.0303

African Parks (2017). https://www.african-parks.org/newsroom/press-releases/73-kilograms-ofgiant-pangoli $\underline{\text { n-scales-seized-by-rangers-in-democratic-republic-of-congo }}$

Bahige, M. (2009). Socio-Economic Study of Local Communities of the Forest Reserve of Yoko (Eastern Province, DRC). M.Sc. Thesis, Kisangani: University of Kisangani.

Boakye, M. K., Kotzé, A., Dalton, D. L., \& Jansen, R. (2016). Unravelling the Pangolin Bushmeat Commodity Chain and the Extent of Trade in Ghana. Human Ecology, 44, 257-264. https://doi.org/10.1007/s10745-016-9813-1

Boakye, M. K., Pietersen, D. W., Kotzé, A., Dalton, D. L., \& Jansen, R. (2015). Knowledge and Uses of African Pangolins as a Source of Traditional Medicine in Ghana. PLoS ONE, 10, e0117199. https://doi.org/10.1371/journal.pone.0117199

Caspary, H. U. (1999). Wildlife Utilization in Côte d'Ivoire and West Africa: Potentials and Constraints for Development Cooperation.

Challender, D. W. S. (2011). Asian Pangolins: Increasing Affluence Driving Hunting Pressure. TRAFFIC Bulletin, 23, 2008-2009.

Challender, D. W. S., \& Hywood, L. (2012). Under Increased Pressure from Poaching and Intercontinental Trade. TRAFFIC Bulletin, 24, 53-55. http://www.traffic.org/bulletin

Challender, D. W. S., \& Waterman, C. (2017). Implementation of CITES Decisions 17.239 $b$ and 17.240 on Pangolins (Manis spp.). CITES SC69 Doc. 57 Annex 1. Geneva: CITES. https://cites.org/sites/default/files/eng/com/sc/69/E-SC69-57-A.pdf

Challender, D. W., \& MacMillan, D. C. (2014). Transforming Wildlife Trade Interventions: Reply to Phelps et al. Conservation Letters, 7, 497-498.

https://doi.org/10.1111/conl.12101

Colyn, M., Dudu, A., \& Mankoto, M. (1987). Exploitation of Small and Average Size Game in the Zaire Rain Forests. Nature and Fauna, 3, 22-39.

Fa, J. E., \& Peres, C. A. (2001). Game Vertebrate Extraction in African and Neotropical Forests: An Intercontinental Comparison. In J. D. Reynolds, G. M. Mace, J. G. Robinson, \& K. H. Redford (Eds.), Conservation of Exploited Species (pp. 203-241). Cambridge: Cambridge University Press.

Gomez, L., \& Leupen, B. (2016). The Trade of African Pangolins to Asia: A Brief Case Study of Pangolin Shipments from Nigeria. TRAFFIC Bulletin, 28, 3-5.

Heusch, L., Douglas, M., \& Lewis, I. (1993). Hunting the Pangolin. Man, New Series, 28, 159-166.

Ichu, I. G., Nyumu, J. K., Moumbolou, C. L. M., Nchembi, F. T., \& Olson, D. (2017). Testing the Efficacy of Field Surveys and Local Knowledge for Assessing the Status and Threats to Three Species of Pangolins in Cameroon. A Report of the MENTOR-POP (Progress on Pangolins) Fellowship Program, Yaoundé: Zoological Society of London Cameroon.

Ingram, D. J., Coad, L., \& Scharlemann, J. P. W. (2016). Hunting and Sale of Pangolins across Sub-Saharan Africa: A Preliminary Analysis. OFFTAKE. http://sro.sussex.ac.uk

Ingram, D. J., Coad, L., Abernethy, K. A., Maisels, F., Stokes, E. J., Bobo, K. S., Breuer, T., Gandiwa, E., Ghuirghi, A., Greengrass, E., Holmern, T., Kamgaing, T. O. W., Ndong Obiang, A.-M., Poulsen, J. R., Schleicher, J., Nielsen, M. R., Solly, H., Vath, C. L., Wal- 
tert, M., Whitham, C. E. L., Wilkie, D. S., \& Scharlemann, J. P. W. (2018). Assessing Africa-Wide Pangolin Exploitation by Scaling Local Data. Conservation Letters, 11, e12389. https://doi.org/10.1111/conl.12389

IUCN (2019). The IUCN Red List of Threatened Species. http://www.iucnredlist.org

Kingdon, J., \& Hoffmann, M. (2013). Mammals of Africa: Volume V Carnivores, Pangolins, Equids and Rhinoceroses. London: Bloomsbury Publishing.

Mahmood, T., Hussain, R., Irshad, N., Akrim, F., \& Nadeem, M. S. (2012). Illegal Mass Killing of Indian Pangolin (Manis crassicaudata) in Potohar Region, Pakistan. Pakistan Journal of Zoology, 44, 1457-1461.

Malimbo, D. K., Nyumu, K. J., Vitekere, K. M., Benzeth Visando, B., Juakaly, M. J., Guy, Cr. T. G., Francis, T. F., \& Hua, Y. (2020). Exploitation of Pangolins (Pholidota, Mammalia) by Communities Living in and around the Tayna Nature Reserve (RNT) North Kivu, Democratic Republic of Congo (DRC). Journal of Geoscience and Environment Protection, 8, 1-17. https://doi.org/10.4236/gep.2020.84001

Mambeya, M. M. et al. (2018). The Emergence of a Commercial Trade in Pangolins from Gabon. African Journal of Ecology, 56, 601-609. https://doi.org/10.1111/aje.12507

Mbete, R. A. (2012). Household Bushmeat Consumption in Brazzaville, the Congo [PhD Thesis]. Liége: Universite de Liége.

Nash, H. C., Wong, M. H., \& Turvey, S. T. (2016). Using Local Ecology Knowledge to Determine Status and Threats of the Critically Endangered Chinese Pangolin (Manis pentadactyla) in Hainan, China. Biological Conservation, 196, 189-195. https://doi.org/10.1016/j.biocon.2016.02.025

Nasi, R., Taber, A., \& van Vliet, N. (2011). Empty Forests, Empty Stomachs? Bushmeat and Livelihoods in the Congo and Amazon Basins. International Forestry Review, 13, 355-368. https://doi.org/10.1505/146554811798293872

Pantel, S., \& Anak, N. A. (2010). A Preliminary Assessment of Pangolin Trade in Sabah. TRAFFIC Southeast Asia, Petaling Jaya. https://www.traffic.org

Pietersen, D., McKechnie, A. E., \& Jansen, R. (2014). Home Range, Habitat Selection and Activity Patterns of an Arid-Zone Population of Temminck's Ground Pangolins, Smutsia temminckii. African Zoology, 49, 265-276. https://doi.org/10.1080/15627020.2014.11407642

Shepherd, C. R., Connelly, E., Hywood, L., \& Cassey, P. (2017). Taking a Stand against Il-Legal Wildlife Trade: The Zimbabwean Approach to Pangolin Conservation. Oryx, 51, 280-285. https://doi.org/10.1017/S0030605316000119

Sodeinde, O. A., \& Adedipe, S. R. (1994). Pangolins in South West Nigeria Current Status and Prognosis. Oryx, 28, 43-50. https://doi.org/10.1017/S0030605300028283

Soewu, D. A., \& Adekanola, T. A. (2011). Traditional Medical Knowledge and Perception of Pangolins (Manis sps) among the Awori People, Southwestern Nigeria. Journal of Ethnobiology and Ethnomedicine, 7, Article No. 25. https://doi.org/10.1186/1746-4269-7-25

Soewu, D. A., \& Ayodele, I. A. (2009). Utilisation of Pangolin (Manis sps) in Traditional Yorubic Medicine in Ijebu Province, Ogun State, Nigeria. Ethnobiology and Ethnomedicine, 5, Article No. 39. https://doi.org/10.1186/1746-4269-5-39

Soewu, D. A., \& Sodeinde, O. A. (2015). Utilization of Pangolins in Africa: Fuelling Factors, Diversity of Uses and Sustainability. International Journal of Biodiversity and Conservation, 7, 1-10. https://doi.org/10.5897/IJBC2014.0760

Turvey, S. T., Trung, C. T., Quyet, V. D., Nhu, V. H., Thoai, D. V., Tuan, V. C. A., Hoa, D. T., Kacha, K., Thanh, N. V., \& Wilkinson. N. M. (2015). Interview-Based Sighting 
Histories Can Inform Regional Conservation Prioritization for Highly Threatened Cryptic Species. Journal of Applied Ecology, 52, 422-433.

https://doi.org/10.1111/1365-2664.12382

Vallianos, C., \& Challender, D. (2016). Pangolins on the Brink. San Francisco: WildAid. https://wildaid.org/sites/default/files/resources/WildAid-Pangolins\%20

Van Vliet, N., \& Mbazza, P. (2011) Recognizing the Multiple Reasons for Bushmeat Consumption in Urban Areas: A Necessary Step toward the Sustainable Use of Wildlife for Food in Central Africa. Human Dimensions of Wildlife, 16, 45-54. https://doi.org/10.1080/10871209.2010.523924

Van Vliet, N., Nasi, R., Abernethy, K., Fargeot, Ch., Kumpel, N. F., Obiang, A. M. N., \& Ringuet, S. (2012). The Role of Wildlife for Food Security in Central Africa: A Threat to Biodiversity? Luxembourg: Publications Office of the European Union.

https://www.cifor.org

Van Vliet, N., Nebesse, C., \& Nasi, R. (2014). Bushmeat Consumption among Rural and Urban Children from Province Orientale, Democratic Republic of Congo. Oryx, 49, 165-174. https://doi.org/10.1017/S0030605313000549

Vitekere, K. (2015). Characterization of the Bushmeat Trade Circuit in Kisangani (DRC): First and Second Levels of the Sector, Ituri Road, PK 122 and 147. M.Sc. Thesis, Kisangani: University of Kisangani.

Waterman, C., Pietersen, D., Hywood, L., Rankin, P., \& Soewu, D. (2014). Smutsia gigantea. The IUCN Red List of Threatened Species.

Willcox, A. S., \& Nambu, D. M. (2007). Wildlife Hunting Practices and Bushmeat Dynamics of the Banyangi and Mbo People of Southwestern Cameroon. Biological Conservation, 2, 251-261. https://doi.org/10.1016/j.biocon.2006.08.016

Willcox, D., Nash, H. C., Trageser, S., Kim, H. J., Hywood, L., Connelly, E., Ichu, I. G., Kambale, N. J., Mousset, M. C. L., Ingram, D. J., \& Challender, D. W. S. (2019). Evaluating Methods for the Detection and Ecological Monitoring of Pangolins (Pholidota: Manidae). Global Ecology and Conservation, 17, e00539. https://doi.org/10.1016/j.gecco.2019.e00539

Wright, H., \& Priston, N. (2010). Hunting and Trapping in Lebialem Division, Cameroon: Bushmeat Harvesting Practices and Human Reliance. Endangered Species Research, 11, 1-12. https://doi.org/10.3354/esr00244

Wu, S., Liu, N., Zhang, Y., \& Ma, G. (2004). Assessment of Threatened Status of Chinese Pangolin (Manis pentadactyla). Chinese Journal of Applied \& Environmental Biology, 10, 456-461. 